\title{
Synergistic Compositions of Traditional Medicine (SIDDHA) against Perilous +ssRNA Coronavirus a Future Alternative Medicine - A Mini Review
}

\section{King Solomon Ebenezer ${ }^{1,2 *}$, Chidambaram Tamilselvan ${ }^{1}$, Rekha Manivanan $^{2}$, Sundaram Ravikumar ${ }^{3}$ and Pandi Boomi ${ }^{4}$}

${ }^{1}$ Drug Testing Laboratory, Bioscience Research Foundation, Chennai, Tamilnadu, India

${ }^{2}$ Department of Toxicology, Bioscience Research Foundation, Chennai, Tamilnadu, India

${ }^{3}$ Department of Biomedical Science, Alagappa University, Karaikudi, Tamilnadu, India

${ }^{4}$ Department of Bioinformatics, Alagappa University, Karaikudi, Tamilnadu, India

*Corresponding Author: King Solomon Ebenezer, Bioscience Research Foundation, Chennai, India.
Received: December 17, 2020

Published: March 20, 2021

(C) All rights are reserved by King Solomon

Ebenezer., et al.

\begin{abstract}
Siddha medicinal system is an admirable ancient symbol of Tamil culture and used from time immemorial in India which is originated in Tamil Nadu and invented from Dravidian culture by the Siddhars (Tamil sages). Globally, siddha drugs are considered to be an important alternative to modern allopathic drugs, also the siddha product and research is very popular for the drug discovery process. The siddha medicinal system is well versed in treating diseases, even incurable by the allopathic practitioners, but their mode of action remained a mystery all these years resulting in their unpopularity in the modern world. The recent alarming rise of novel deadly viral infections in the society demands novel drugs for treatment and made the researchers looking into the alternative therapies. Hence, recently many researchers are forthcoming in evaluating the antiviral activity of the siddha drugs using modern scientific approaches. In context to this, this mini review summarizes the synergistic compositions of siddha drugs and their efficacy against pathogenic single strand positive sense RNA coronavirus disease.
\end{abstract}

Keywords: Corona Virus; Siddha; Drugs; Traditional Medicine; Alternative Medicine

\section{Abbreviations}

RNA: Ribonucleic Acid; SARS CoV: Severe Acute Respiratory Syndrome Coronavirus; MERS CoV: Middle East Respiratory Syndrome Coronavirus; COVID: Coronavirus Disease; ACE2: Angiotensin Converting Enzyme 2; HCoV: Human Coronavirus; API: Active Pharmaceutical Ingredients; APCI: Active Pharmaceutical Complex Ingredients; AYUSH: Ayurvedic Unani Sidda Homeopathy; mg: milligram; ml: milliliter; GC-MS: Gas Chromatography- Mass spectrometry

\section{Introduction}

Siddha system of medicine is an ancient science practiced by traditional 'Siddha Vaidyar' families and qualified 'Siddha Physicians' in the state of Tamil Nadu in India. The original manuscripts are in the form of ever green 'Palm Leaf Scripts' [1]. This system of public health medicine is confined to 7.2 million populations of Tamil speaking people in the State and today practiced at par with allopathic system of medicine under the recognition of Government of India [2]). 
Siddha medicine was formulated by '18 Siddhars', the ancient saints of Tamil Nadu who mastered the art and science of life and well-being of people. They were the best intellectuals in ancient times of Tamil Nadu and the team of Scientists who designed Siddha Medicine Systems. The significant contributions of some Siddhars like Shri. Agasthiar, Shri. Bohar and Shri. Patanjali were noteworthy to mention. Hence it is called as 'Siddha Medicine' and also popularly known as Tamil Medicine [3]. This ancient science has millions of scripts and prescribed methods, standards and systems for the diagnosis of diseases, preparation of drugs and methods of treatments for various ailments entirely based on the natural ingredients well compatible with the nature, humans and the environment. Siddha the only Public Health Medical System available in Tamil Nadu, practiced by Traditional siddha vaidyars and their families in almost every village before the establishment of European Colonies who later popularised western science or modern science and Allopathic system of medicines.

The basic concept of siddha depends on synergistic compositions of drugs for cure of diseases which is similar to the synergistic compositions of food materials undergoing a process of digestion, absorption, assimilation and transformation into fundamental units of life through human body. The proverb in traditional Siddha system, 'Food makes Medicine' and 'Medicine makes Food' shares the commonality of the concept of synergistic compositions between food and Siddha drugs both are biologically well compatible with the human system. Example: A common Siddha clinical practice followed in most part of Tamil Nadu is the administration of a homemade Siddha drug preparation for post natal care of women folks with an aim to rejuvenate and revitalise her body systems and to develop immunity to her new born child. This ancient practice is prevalent in almost all the villages of Tamil Nadu despite the fact that these rural women folks give birth to their children under allopathic system of care and maintenance during delivery in Government Hospitals, Primary Health Centres or Private Clinics. This is a typical example of a deep and well rooted Siddha traditional practice in Tamil Nadu beyond the modern allopathic system of medicine. This post natal treatment demonstrates the absolute safety and the excellent benefit of Siddha drugs in highly sensitive stages of life of a human being. The ancient population has been using Siddha drugs for generations for the treatment of various diseases for new born babies, pregnant women and all other age groups. This is an ancient and indisputable medical science of the people of Tamil Nadu [4].

Coronaviruses, a positive sense single stranded RNA virus that causes respiratory tract infections in humans and infections are mild and acute, the lethal infections SARS CoV in 2003, MERS CoV in 2012 and SARS CoV2 in 2019 have been a major public health concern around the globe [5]. COVID 19, the pandemic disease caused highest mortality rate around the world. The virus is affecting 213 countries and territories around the world after its outbreak in December 2019 at Wuhan district, China. The virus spreads from one person to another through respiratory droplets or an aerosol released during sneezing or coughing and affects the person's immune system. The major effects are fever and respiratory illness [6].

The clinical studies have indicated that the main symptoms of the disease are fever, cough and dyspnea. There are some cases that do not show any clinical signs of illness [7]. In host (humans), the spike (S) protein in virus binds to the ACE2 cellular receptor enabling the entry of viral RNA within the host cell responsible for infections [8]. The coronavirus group belongs to the family Coronaviride contains an enveloped virion particle of approximately 120 $\mathrm{nm}$ diameter. The family Coronaviride contains two subfamilies Coronavirinae and Torovirinae with a further division of six genera namely Alphacoronavirus, Betacoronavirus, Gammacoronavirus, Deltacoronavirus, Torovirus, and Bafinivirus [9]. The virus surface is covered with spikes or smaller projections, hemagglutinin. The coronavirus encoded with four structural proteins, the spike, glycoprotein, the integral membrane protein and the nucleocapsid protein [10].

The first reported case of human by Coronavirus dates back to the late 1960s by two strains HCoV-229E and HCoV-OC43. These strains produced mild upper respiratory tract infection and common cold, but later in 2003 , the severe acute respiratory syndrome (SARS) Coronavirus has caused a serious illness globally leading to the discovery of two new strains of human Coronavirus HCoV-NL63 and CoV-HKU1 in Netherlands and China. Further in the early 2012, the novel Middle East Respiratory Syndrome (MERS) Coronavirus has also caused fatal illness in the Middle East and then spread to the Europe and North Africa. MERS CoV was previously known as human betacoronavirus 2c EMC/2012 and human coronavirus HCoV EMC [11,12]. There are no allopathic medicines or vaccines approved for these diseases; still under

Citation: King Solomon Ebenezer., et al. "Synergistic Compositions of Traditional Medicine (SIDDHA) against Perilous +ssRNA Coronavirus a Future Alternative Medicine - A Mini Review". Acta Scientific Pharmaceutical Sciences 5.4 (2021): 55-66. 
research. Treatment is solely based on treating the symptoms caused by the virus.

\section{Synergistic of siddha medicine}

The greater therapeutic potential of the herbs based traditional medicines including siddha is a result of the synergistic effect of the different herbs used in the formulation. The combination of two or more herbs exhibited greater efficacy than their single herb compounds by synergism by a mechanism thereof overcomes the microbial resistance, different herbs targets either different or same sites, regulation of enzymes involved in oral bioavailability, drug to drug interactions resulting in elimination of side effects and enhancement of pharmacological efficacy [13].

In siddha, two broad categories of synergistic compositions of medicine are prepared in Siddha; one is based on simple admixtures of various plant materials and the other is a complex preparation of synergistic compositions. There are medicine made out of simple admixtures of various plant materials, minerals, acids, alkalis and oils blended together to work synergistically to cure the diseases. There are also medicine of complex preparations made out of various plant materials, minerals, acids, alkalis, oils and metals through a perfect process of manufacturing supported by standards for quality assurance. These medicines undergo a process of blending, heating to micronisation and vaporization to condensation to make a drug of unparalleled therapeutic value (Figure 1). Examples are Arumuga Sendhooram, Karuvangam and Sandamarudham. These two concepts of medicines give rise to different kinds of medicines called Kashayams, Oils, Legiyams, Sooranams, Paspams and Sendhoorams.

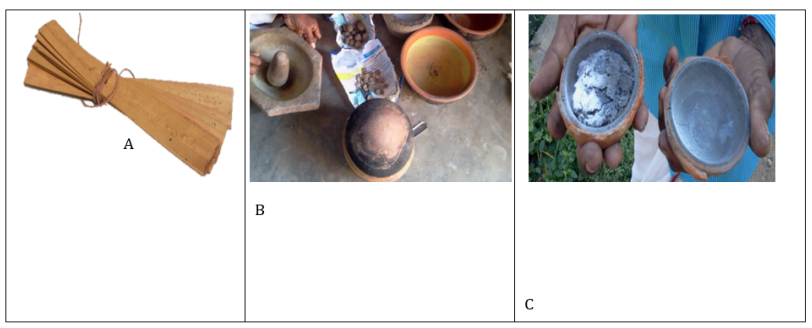

Figure 1: A) Siddha manuscripts in palm leaves; (B) and (C): raw materials and apparatuses used in preparation of traditional siddha drugs.
Siddha medicines are made out of many ingredients subjected to a robust process of manufacture starting from simple blending to a complex method of purification, micronisation and heating to condensation. In fact it is no lesser than the chemically complex synthetic processes of allopathic Active Pharmaceutical Ingredients (API) which are prepared into various formulated products for treatments. Siddha medicines undergo similar reactions and stepwise manufacturing processes but with an additional step of 'purification' of raw materials known as 'Sutthi' to transform ordinary raw materials into valuable therapeutic agents and to obtain an 'Active Pharmaceutical Complex Ingredients' (APCI) as an end product directly used for treatment of diseases. A comparison of the synthesis of allopathy and traditional siddha medicines is made by the authors with the modern understanding of the concept of synthetic pathway of drugs (Table 1). Siddha medicines are administered either directly or together with other food ingredients like Jaggery, Honey, and Fruit extracts, Milk, Curd, Buttermilk, Ghee and Butter.

\section{Synthetic process of allopathy and siddha drugs}

\begin{tabular}{|l|c|}
\hline $\begin{array}{l}\text { Synthesis of Active } \\
\text { Pharmaceutical } \\
\text { Ingredient (API) in } \\
\text { Allopathic Drugs }\end{array}$ & $\begin{array}{c}\text { Synthesis of Active } \\
\text { Pharmaceutical Complex } \\
\text { Ingredients (APCI) in Siddha } \\
\text { Drugs }\end{array}$ \\
\hline $\begin{array}{l}\text { Natural \& Synthetic Raw } \\
\text { Materials Used }\end{array}$ & $\begin{array}{c}\text { Only Natural Raw Materials } \\
\text { Used After } \\
\text { Purification by 'Sutthi' }\end{array}$ \\
\hline $\begin{array}{l}\text { Reactions comprising } \\
\text { by Blending or Heating } \\
\text { or Boiling or Cleaning is } \\
\text { General Process }\end{array}$ & $\begin{array}{c}\text { Reactions comprising Blending } \\
\text { or Heating or Cleaning is } \\
\text { General Process }\end{array}$ \\
\hline Yield of API & \begin{tabular}{c} 
Yield of APCI \\
\hline $\begin{array}{l}\text { Drug Yield is Single Active } \\
\text { Pharmaceutical Ingredient }\end{array}$
\end{tabular} \\
$\begin{array}{l}\text { Drug Yield is Synergistic Active } \\
\text { Pharmaceutical Complex } \\
\text { Ingredients }\end{array}$ \\
$\begin{array}{l}\text { products formed during } \\
\text { manufacturing process }\end{array}$ & $\begin{array}{c}\text { No Impurities and No } \\
\text { By-Products formed during } \\
\text { mafacturing process because } \\
\text { lack of standard analytical } \\
\text { methods }\end{array}$ \\
\hline $\begin{array}{l}\text { API is made into } \\
\text { formulated Drugs for }\end{array}$ & $\begin{array}{c}\text { APCI is administered directly as } \\
\text { Drugs for treatment }\end{array}$ \\
\hline
\end{tabular}

Table 1: Comparison between synthesis of allopathy and siddha drugs. 
These are called as 'Anubanams' and they themselves believed to have no therapeutic value but makes value addition in administration. These substances are known to facilitate absorption and assimilation of medicinal substances at particular part of the alimentary canal at a preferred time of intake and also known to reduce the undesirable effects on some parts of the body where the medicinal substance is not required to be absorbed or exposed or acted and there are significant differences experienced in clinical practices for generations of use by 'Siddha Vaidyars.

Siddha system of diagnosis and classification of diseases are unique and are based on the anatomical and physiological features of the human body largely depend on the environmental factors which are nothing but changes in planets especially solar and lunar cycles. Diseases are diagnosed through the variations in the magnitude of the three 'Dhosas' called Vadam, Pittam and Kabam. This is also called as 'Naadi' and observed just below the wrist bone by applying slight pressure by the three fingers on the three Naadis to read and interpret the physiological and pathological conditions of the body in terms of various diseases (Figure 2). There are also Naadi observations to understand even minor changes of hormones in the body including diagnosis and determination of stages of pregnancy. This art and science is learned through the training given by forefathers and carried through generations and maintained as family secrets. Naadi diagnosis is closely related to the changes in the outside environment, planetary changes such as lunar cycles and solar cycles with annual geological changes are believed to affect the functioning of every human body on this earth.

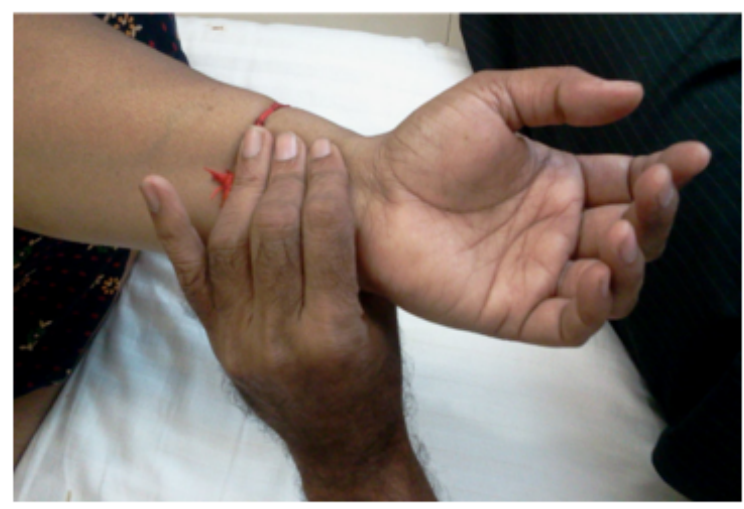

Figure 2: Diagnosis of diseases through modulation of vadham, pittam and kabham as naadi.
Siddha has answers for today's major challenges of modern system of medicines such as solutions to fast changing patterns of mutations and resistance in pathogens causing viral and bacterial diseases.

Siddha medicine is well known to tackle complex biological phenomenon with excellent clinical records of practice. Lots of success stories of treating patients with siddha medicine during the last few successive outbreaks of viral diseases in Chennai, Tamil $\mathrm{Nadu}$, India. Yet another special feature of siddha medicines is that the diseases are cured without deteriorating the immune system.

The biggest advantage of siddha medicines is the total dependence on natural ingredients, while the major disadvantage is the lack of preclinical pharmacological evidences to demonstrate the mode of action and risk assessment facing challenges from modern science and allopathic practitioners. New research methodologies combined with a perfect understanding of traditional knowledge will bring out the benefit of these wonder medicine to the people suffering out of infectious and chronic diseases all over the world. Research is under progress to design and develop innovative tools and techniques to demonstrate the mode of action and risk assessment of synergistic compositions of these traditional medicines [14].

The Ministry of AYUSH, Ministry of Health and Family Welfare, New Delhi, has designated set of protocols for testing the siddha medicines. The physiochemical analysis includes $\mathrm{pH}$, loss on drying, total ash, acid insoluble ash, water soluble extractive, estimation of sulphur and mercury, the phytochemical screening for the determination of metabolites includes Morquies test, Mayers test, Dragendorffs test, Hayers test, Wagners test, Test for Quinine (Bromine - ammonia test), Test for Morphine (Iodic acid test), Test for Terpenoids (Leibermann Buchard test), Test for Flavanoids (Shinoda's test), Test for Methylene dioxy group (Labat test), Test Phenols OH group (FeCl3 test) along with HPLC, TLC analysis [15].

\section{Siddha drugs against coronavirus}

The most dangerous positive sense single strand RNA coronavirus is epidemic disease and so far there are no allopathic medicines discovered for the diseases. However, in siddha medicinal system, the infections are treated effectively using various herbal preparations and polyherbal formulations in Tamil Nadu. But the herbal drugs are not considered in the light of modern medicinal

Citation: King Solomon Ebenezer., et al. "Synergistic Compositions of Traditional Medicine (SIDDHA) against Perilous +ssRNA Coronavirus a Future Alternative Medicine - A Mini Review". Acta Scientific Pharmaceutical Sciences 5.4 (2021): 55-66. 
system due to the lack of preclinical pharmacological evidences as mentioned earlier. The efficacy of nilavembu kudineer as antiviral for arboviruses using cytotoxicity assay and observed that the herbal formulation provided protection against the viruses during the active infection and also prevented the cell infection. Nilavembu kudineer is the common herbal formulation used in siddha treatment regimen for viral diseases [16].

It is a polyherbal concoction containing nilavembu (Andrographis paniculata), vetiver (Vetiveria zizanioides), Vilamiccam ver (V. zizanioides), Cantanam (Santalum album), Peyputtal (Trichosanthes cucumerina), Koraik kilanku (Cyperus rotandus), Cukku (Zingeber officinale), Milaku (Piper nigrum) and Parpatakam (Mollugo cerviana). Andrographis paniculata is the main ingredient of the concoction effective against all types of fever associated with body ache. Further they reported that the extraction procedure is as important to ensure maximum efficacy of the formulation (Figure 3). Nilavembu kudineer at doses 200 and $400 \mathrm{mg} / \mathrm{kg}$ inhibited fever in a brewer's yeast induced pyrexia mice model [17]. The efficacy of Andrographis paniculata against common cold had been revealed earlier by a pilot double blind trial [18]. In 2015, a case study on 176 cases at National Institute of SIDDHA, Chennai observed the protective effect of Nilavembu kudineer against the Dengue fever when administrated adequately and regularly. Efficacy of Nilavembu kudineer was confirmed by the increase in platelet count through complete blood cell counting in a hematology analyzer [19]. Further large scale control studies are required to confirm the efficacy.

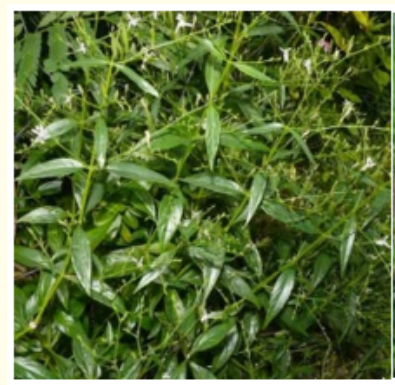

Andrographis paniculata

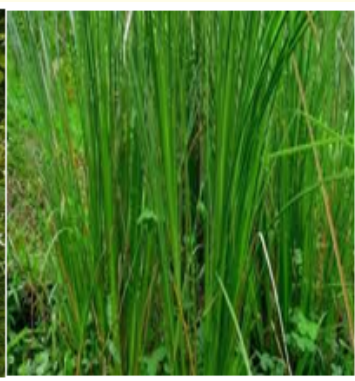

Vetiveria zizanioides

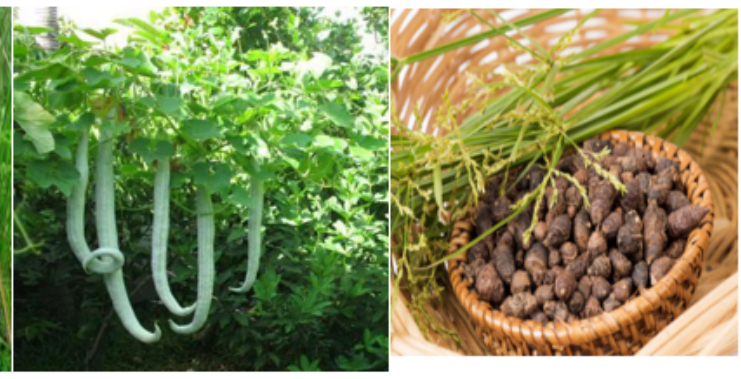

Trichosanthe cucumerina
Cyperus rotandus

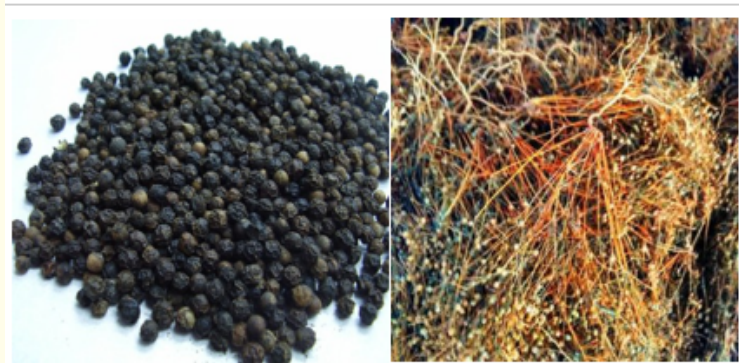

Piper nigrum
Mollugo cerviana

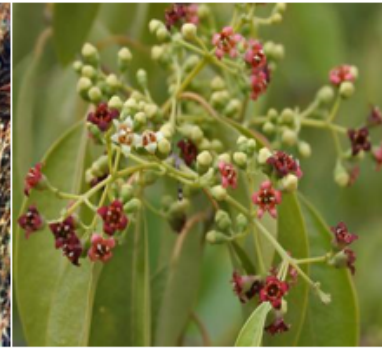

Santalum album

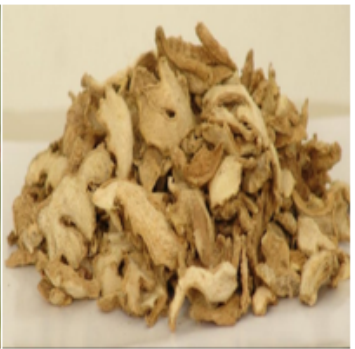

Zingeber officinale

Figure 3: Nilavembu kudineer ingredients.

Brahmanandha bairavam mathirai and Vishnu chakram, the formulations used for viral treatment regime approved by
AYUSH, which able to resist the virus entry into the host cell at concentrations between 0.5 and $0.0625 \mathrm{mg} / \mathrm{ml}$ respectively. 
Brahmanandha bairavam mathirai is used for fever and Vishnu chakram for fever and arthritis in siddha medicine. In spite of the regular use, many clinical studies are yet to be conducted for Brahmanandha bairavam mathirai and Vishnu chakram.

Amukara choornam is the polyherbal formulation used for treating virus in the post pyretic phase which presents with severe arthritis pain from months to years. The plant Withania somnifera is the important ingredient in this formulation contributing to $60 \%$ of the constituents, also widely used in the Indian and Chinese natural medicine system for conditions like arthritis and rheumatism [20]. The viral clearance in the brain and muscle joints depicts the immunomodulatory effect of the formulation. Cytotoxicity assay analysis of Amukara choornam formulation in water showed concentration below $30 \mathrm{mg} / \mathrm{mL}$ was nontoxic [21]. The plant Withania somnifera having anti-inflammatory, neuroprotective and immunomodulatory effects supports the efficacy of amukara chooranam [22]. However, in Tamilnadu the siddha practitioners suggested the use of Kabasura kudineer, a poly herbal formulation as an immunomodulatory drug against the SARS CoV2. In siddha medicinal system there are many such formulations, like Kabasura kudineer, to treat various kinds of fever and respiratory illnesses. Through insilico docking, in vitro and in vivo methods, the researchers are evaluating their inhibitory effects against the virus and to create scientific evidence for the drug discovery process.

The efficacy of Kabasura kudineer and Thonthasura kudineer, poly herbal formulations against the coronavirus spike proteins evaluated by in silico docking analysis. Both these formulations are used to treat fever due to respiratory infections [23]. On acute toxicity study, Kabasura kudineer exhibited no lethality and no neurotoxicity at $2000 \mathrm{mg} / \mathrm{kg}$ dose in rats and showed a significant antipyretic effect at doses 200 and $400 \mathrm{mg} / \mathrm{kg}$, comparable to that of paracetamol $(150 \mathrm{mg} / \mathrm{kg})$ when screened by brewer's yeast induced pyrexia model in wistar albino rats [24]. For Thonthasura kudineer clinical efficacy and cytotoxicity data are yet to be discovered.

Kabasura kudineer formulation consisted of the herbs Chukku (Zingiber officinale), Thippili (Piper longum), Kirambu (Syzygium aromaticum), Sirukanchori (Tragia involucrate), Akkirakaram (Anacyclus pyrethrum), Mulliver (Hygrophilla auriculata), Kadukkaithol (Terminaliac chebula), Adathodai (Adathoda vasica), Karpuravalli (Plectranthusamboinicus), Kostam (Saussureal lappa), Seendhil (Tinospora cordifolia), Ciruthekku (Clerodendrum serratum), Nilavembu (Andrographis paniculata), Vattathiruppi (Sida acuta), Korai kizhangu (Cyperus rotundus) (Figure 4).

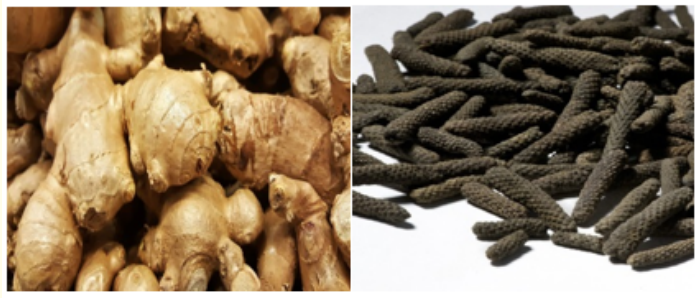

Zingiber officinale

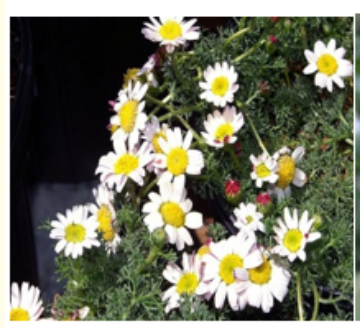

Anacyclus pyrethrum
Piper longum

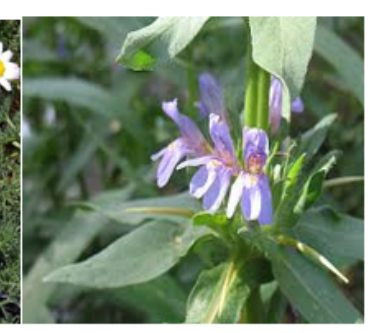

Hygrophilla auriculata

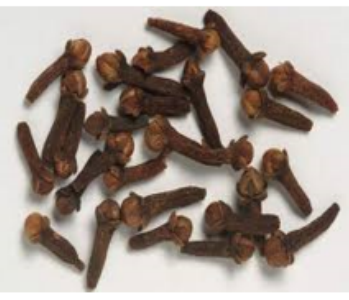

Syzygium aromaticum

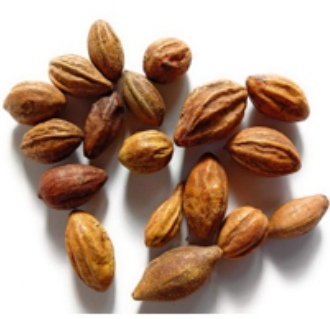

Terminalia chebula

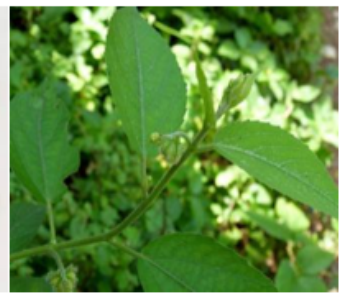

Tragia involucrate

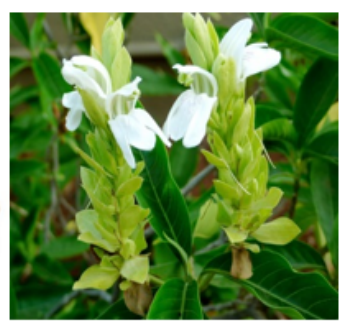

Adathoda vasica

Citation: King Solomon Ebenezer., et al. "Synergistic Compositions of Traditional Medicine (SIDDHA) against Perilous +ssRNA Coronavirus a Future Alternative Medicine - A Mini Review". Acta Scientific Pharmaceutical Sciences 5.4 (2021): 55-66. 


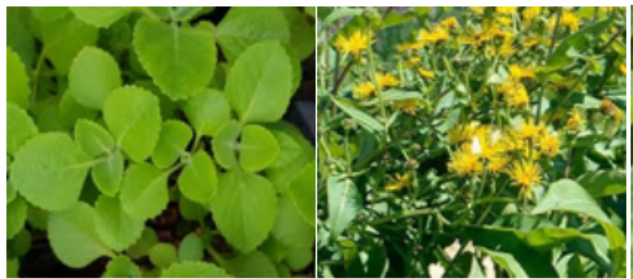

Plectranthusamboinicus Saussureal lappa

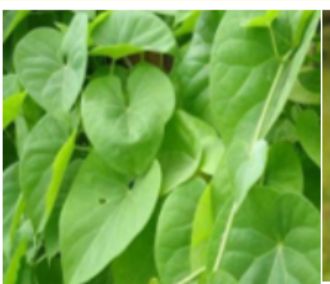

Tinospora cordifolia

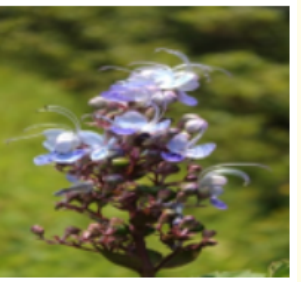

Clerodendrum serratum

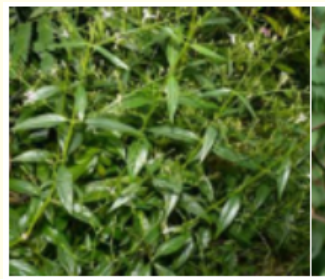

Andrographis

paniculata

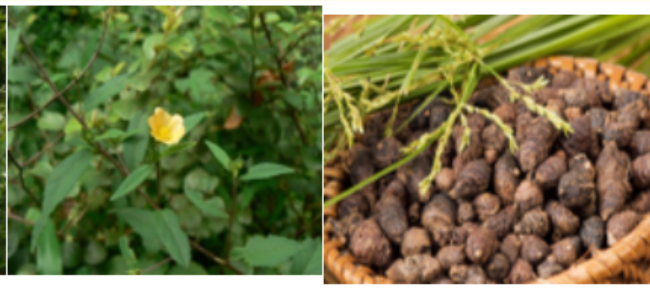

Sida acuta

Figure 4: Kabasura kudineer ingredients.

Thonthasura kudineer is a formulation of herbs like Chukku (Zingiber officinale), Adathodai (Adathoda vasica), Nilavembu (Andrographis paniculata), Seendhil (Tinospora cordifolia), Elam (Ellettaria cardamomum), Kandangathri (Solanum xanthocarpum),
Peipudal (Trichosanthes cucumerina), Mutkavelai (Tephrosia purpuria), Parpadgam (Mollugo cerviana) and Thrakshai (Vitis vinifera) (Figure 5).
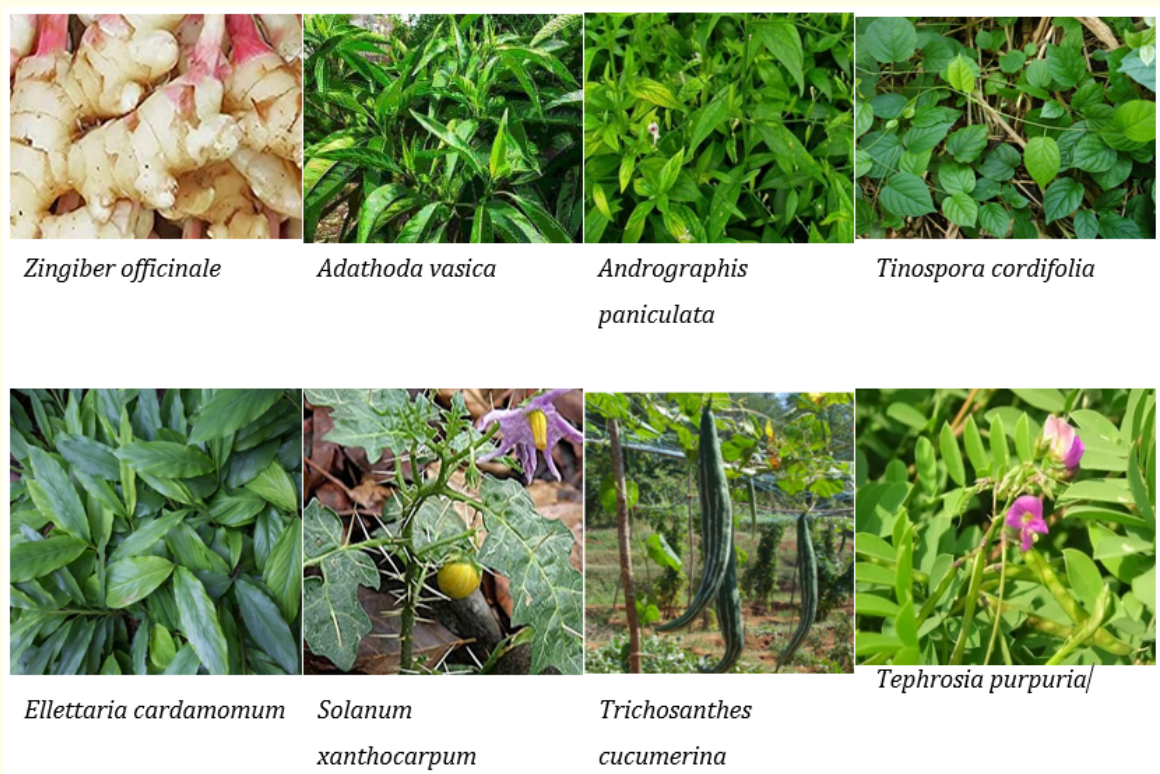

Citation: King Solomon Ebenezer., et al. "Synergistic Compositions of Traditional Medicine (SIDDHA) against Perilous +ssRNA Coronavirus a Future Alternative Medicine - A Mini Review". Acta Scientific Pharmaceutical Sciences 5.4 (2021): 55-66. 


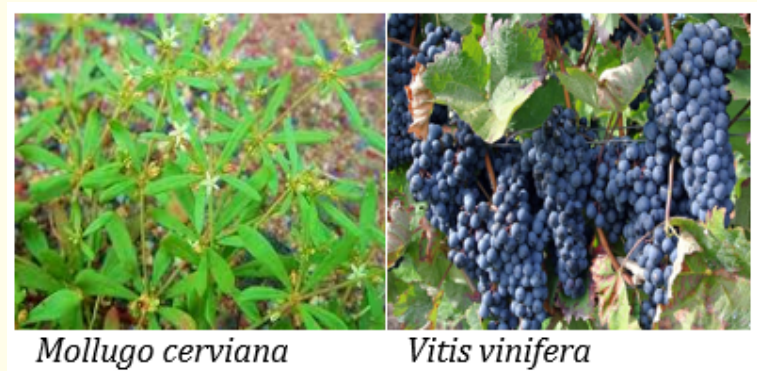

Figure 5: Thonthasura kudineer ingredients.

The in silico docking of the spike protein and phytocompounds of medicinal plants revealed that Trichosanthes cucumerina, Tinospora cordifolia, Hygrophilla auriculata, Anacyclus pyrethrum, Andrographis paniculata, Adathoda vasica, Saussurea lappa, Clerodendrum serratum, Syzygium aromaticum, Zingiber officinale might have the potential to inhibit the virus. Of all phytocompounds Zingeberene, Andrographalide, Vasicine, Cardiofoliate $B$ and Cordiofolioside A were able to bind with $\mathrm{CH}$ region of the spike, which is the most crucial for viral pathogenesis. Other compounds interacted with amino acids of S1 and S2 subunits of spike protein. As a result Kabasura kudineer showed promising higher inhibitory effects against the virus than the Thonthasura kudineer. The docking efficiency of phytocompounds of medicinal plants in Kabasura kudineer and another siddha drug JACOM evaluated with SARS CoV 2. JACOM is the novel patented neuraminidase inhibitor drug against inactivated respiratory viruses [25]. Nine phytocompounds from six medicinal plants namely Sida acuta, Adhatoda vasica, Andrographis paniculata, Tinospora Cordifolia, Costus speciosus, Plectranthus ambonicus had highest binding affinity with the spike protein and with that plants they prepared a novel formulation called SNACK-V to aid in the treatment of COVID 19. Bhumi shah., et al. identified about 54 phytoconstituents in the medicinal plants of Kabasura kudineer, Nilavembu kudineer and JACOM, out of which 30 were able to interact with more than 2 proteins of COVID 19. Notably, the constituents Vasicine, Vasicinone, Luteolin, Scutellarein and Quercetin bound with all the protein structures. They found that half of the ingredients of the three formulations showed effective binding against the novel coronavirus.
Likewise, Kabasura kudineer and thonthasura kudineer, another chooranam, Adathodai kudineer with four ingredients namely Adathoda vasica, Glycyrrhiza glabra, Taxus baccata and Piper longum has been tested by Christian., et al. against the SARS CoV 2 spike protein and ACE2 receptor spike protein complex through molecular docking (Figure 6). In siddha, this formulation is also used to treat various types of fevers and respiratory illnesses, which are also the symptoms of COVID 19 disease [26].

ACE2 is the receptor in human cell that binds the spike protein of coronavirus during viral entry [27]. The docking analysis showed that out of 18 compounds identified in the formulation through GC-MS, alpha copene exhibited higher binding affinity against both spike protein and protein receptor complex suggesting the potency of the formulation to inhibit the coronavirus. An earlier case study revealed the efficacy of Adathodai Manapagu in increasing the platelet count and decreasing packed cell volume in dengue infected children of age 3 and 12 without any adverse side effects in a treatment regime with combination of Nilavembu Kudineer [28]. In a similar study, administration of Adathoda vasica leaves in the treatment regimen of dengue patients along with papaya leaves juice two times a day exhibited a rapid response in increased platelet count in the bone marrow. Even though in silico docking analysis and the case studies confirms the efficacy of the Adathodai Kudineer further large scale clinical trials are required in future to develop into a drug against dengue.

Main Protease and RNA-dependent RNA polymerase of SARS-CoV-2 are two proteins important in the viral replication 


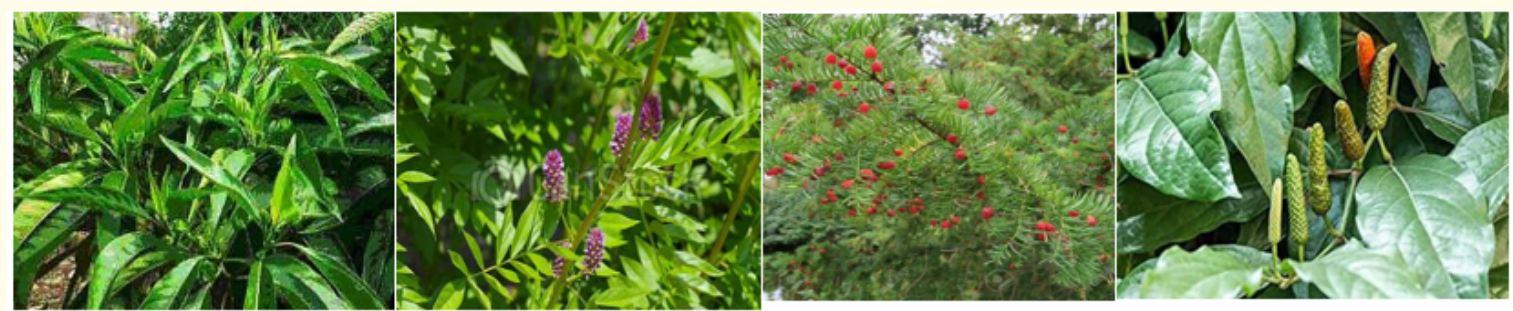

Adathoda vasica

Glycyrrhiza glabra

Taxus baccata

Piper longum

Figure 6: Adathodai kudineer ingredients.

and transcription. The siddha medicine Maramanjal kudineer chooranam targeted against the proteins, consisted of 15 medicinal plants Coscinium fenestratum, Adathodai, Curcuma longa, Piper nigrum, Tracyspermum ammi, Zingiber officianale, Cuminamcyminum, Ocimum sanctum, Solanum trilobatum, Syzygiumaromaticum, Alpinia officinarum, Glycyrrhiza glabra, Picrrorizhakurora, Anacyclus pyrethrum and Piper betle. All the seventy four phytocompounds of the drug formulation exhibited a good binding affinity as ligand against the viral proteins (Figure 7). On the other hand, of seventy four phytocompounds of Kabasura kudineer, 50 docked with the main protease and 42 with the RNAdependent RNA polymerase [29]. Although clinical efficacy of Kabasura Kudineer was being studied, clinical efficacy and toxicity for Maramanjal kudineer chooranam were yet to be studied.
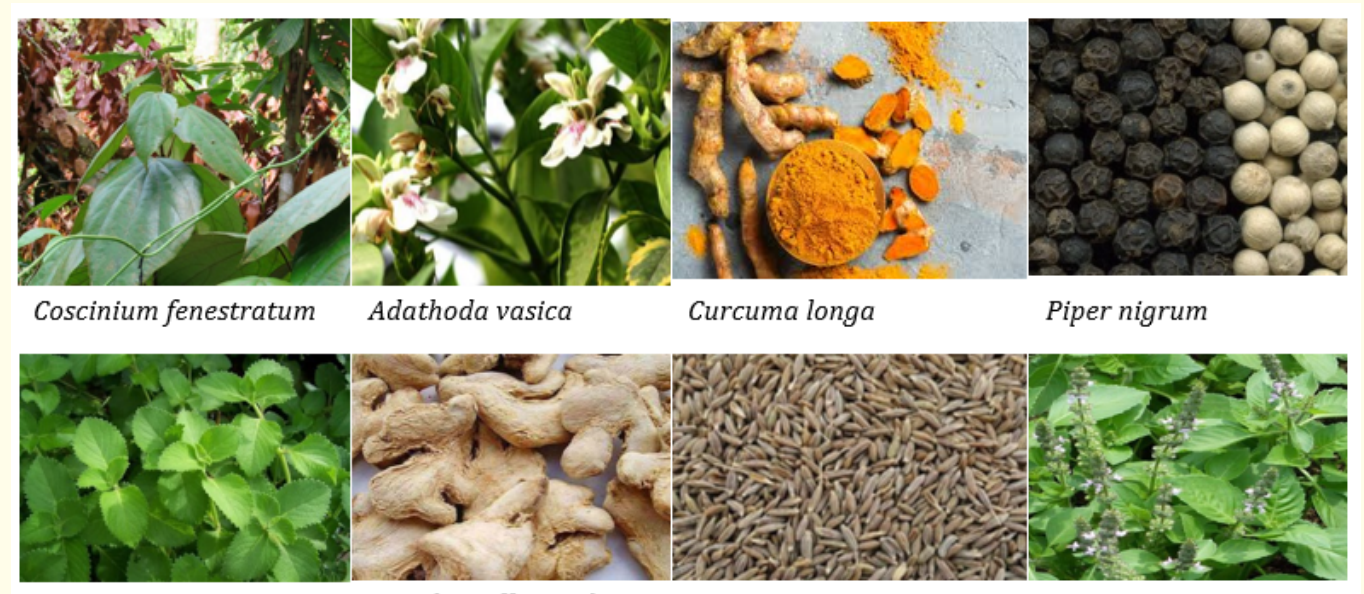

Tracyspermum ammi

Zingiber officianale

Cuminamcyminum

Ocimum sanctum

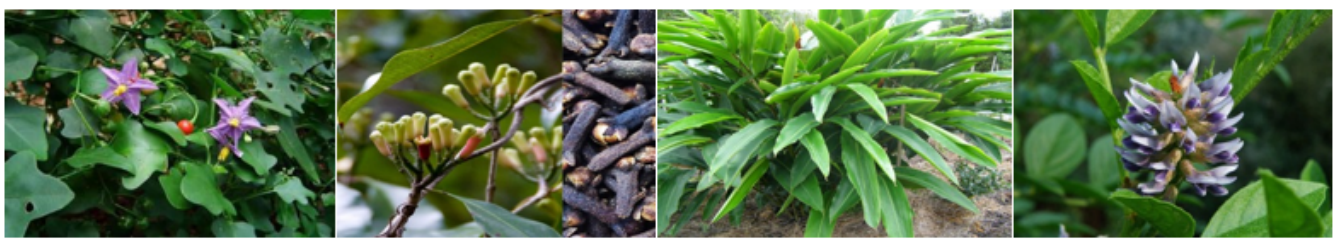

Solanum trilobatum

Syzygiumaromaticum

Alpinia officinarum

Glycyrrhiza glabra

Citation: King Solomon Ebenezer., et al. "Synergistic Compositions of Traditional Medicine (SIDDHA) against Perilous +ssRNA Coronavirus a Future Alternative Medicine - A Mini Review". Acta Scientific Pharmaceutical Sciences 5.4 (2021): 55-66. 


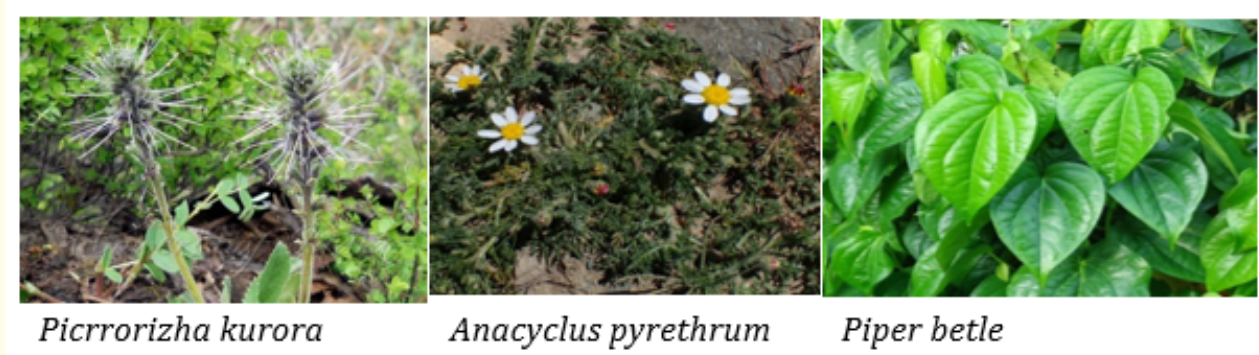

Figure 7: Maramanjal kudineer chooranam.

Traditional understanding based modern research

The fundamental research on the basic understanding of ancient beliefs and concepts of this traditional science and practice with the help of traditional 'Vaidyars' who diagnose, prepare and treat patients using Siddha drugs. A team of modern researchers are working in tandem with Traditional Siddha Vaidyars to explore the fundamentals of Siddha drugs. The existing siddha raw material and traditional apparatuses museum and animal models to suit traditional science based evaluations for a meaningful interpretation supported by modern scientific protocols, tools and techniques for pharmacological evaluations. A world class Siddha Museum to sustain the memories and knowledge of traditional practices of Tamil Nadu for the future generations is under construction.

Efforts are taken to demonstrate the basic understanding of traditional and Vedic science based concept of 'Regeneration and Rejuvenation' in human system through dedicated team of modern scientists. Developing software to read and interpret Naadi system of diagnosis is under progress. A risk assessment program on Siddha drugs includes mutagenic, genotoxic, carcinogenic, reproductive toxic and synergism and potentiation supported by histopathology, haematology, biochemical analysis combined with clinical signs and symptoms is part of our evaluation protocol to address the challenges of modern medicine researchers. Clinical studies are planned for those siddha drugs that have already proven clinically at village scale trials of traditional siddha Vaidhyar families through historical data from Tamil Nadu.

\section{Conclusion}

Siddha medicinal practice is being effectively used in South India especially in Tamilnadu from time immemorial. Siddha medicines exhibit greater therapeutic efficacy in disease management than the allopathic medicines and can provide novel cure for pandemic disease like COVID 19. The globalization of siddha medicines as drugs for novel diseases relies on the conduction of clinical studies. The future studies in siddha medicines should focus on the in vitro and in vivo clinical studies for confirming the safety and efficacy leading to the development of drugs. Through modern computational methods, phytocompunds in the siddha medicinal herbs having binding potential with the viral proteins can be identified rapidly, thus can be isolated for drug discovery process and a novel drug can be developed. Recognition of siddha medicines globally will also develop the socioeconomic status of the country. This review glimpses the path for the scientist, traditional medicine practitioner's and pharma industries to find innovative solutions as a future alternative medicine based on this traditional medicine as a main ingredients through unmet research to cure the pandemic corona viral disease (Covid 19).

\section{Bibliography}

1. Stephen ES. "Complementary and alternative medicine". In: Dennis LK, Eugene B, Anthony SF, Stephen LH, Llarry JL, editors. Harrisons Principles of internal medicine. 16th ed, McGraw-Hill Medical Publishing Division; (2005): 67.

2. Gogtay N., et al. "The Use and Safety of Non-Allopathic Indian Medicines". Drug-Safety (2002): 25, 1005-1019. 
3. Richard S Weiss "Recipes for Immortality: Healing, Religion, and Community in South India: Healing, Religion, and Community in South India". Oxford University Press (2009).

4. Karemore MN and Avari JG. "Herbal medicines used during pregnancy, childbirth and postpartum care". International Journal of Pharmaceutical Sciences and Research 8.12 (2012): 5326-5335.

5. Cui J., et al. "Origin and evolution of pathogenic coronaviruses". Nature Reviews Microbiology 17 (2019): 181-192.

6. Indranil Chakraborty and Prasenjit Maity. "COVID-19 outbreak: Migration, effects on society, global environment and prevention". Science of The Total Environment 728 (2020): 138882

7. Fang Jiang., et al. "Review of the Clinical Characteristics of Coronavirus Disease 2019 (COVID-19)". Journal of General Internal Medicine 35 (2020): 1545-1549.

8. Muhammad Adnan Shereen., et al. "COVID-19 infection: Origin, transmission, and characteristics of human coronaviruses". Journal of Advanced Research 24 (2020): 91-98.

9. De Groot RJ. "Family Coronaviridae”. Virus Taxon, ICTV (2012): 806-820.

10. Linda J Saif. “Coronavirus Immunogens”. Veterinary Microbiology 3.3-4 (1993): 285-297.

11. Nour Ramadan and Houssam Shaib. "Middle east respiratory syndrome coronavirus (MERS-CoV): A review”. Germs 9.1 (2019): 35-42.

12. Jasper FW Chan., et al. "Is the discovery of the novel human betacoronavirus 2c EMC/2012 (HCoV-EMC) the beginning of another SARS-like pandemic?" Journal of Infection 65 (2012): 477-89.

13. Yang Y., et al. "Synergy effects of herb extracts: pharmacokinetics and pharmacodynamic basis". Fitoterapia 92 (2014): 133-147.

14. Sharma PV and Siddha medicine. "In History of Medicine in India" (Ed.) P. V. Sharma. New Delhi: The Indian National Science Academy (1992): 445-45.
15. Muthukumar NJ., et al. "Physico Chemical And Phytochemical Analysis Of Vishnu Chakra Mathirai -A Siddha Herbo Mineral Formalation". Indian Journal of Research 5.6 (2016): 204-207:

16. Jaspreet Jain., et al. "Standardization of in vitro assays to evaluate the activity of polyherbal siddha formulations against Chikungunya virus infection". Virus Disease 29.1 (2018): 32-39.

17. Anbarasu K., et al. "Antipyretic, anti-inflammatory and analgesic properties of Nilavembu kudineer choornam: a classical preparation used in the treatment of chikungunya fever". Asian Pacific Journal of Tropical Medicine (2011): 819-823.

18. Caceres DD., et al. "Prevention of common colds with Andrographis paniculata dried extract. A pilot double blind trial". Phytomedicine 4.2 (1997): 101-104.

19. Christian GJ., et al. "Protective Effect of Polyherbal Siddha Formulation-Nilavembu Kudineer against Common Viral Fevers Including Dengue - A Case-Control Approach". International Journal of Pharmaceutical Sciences and Research 6.4 (2015).

20. Mishra LC., et al. "Scientific basis for the therapeutic use of Withania somnifera (ashwagandha): A review". Alternative Medicine Review 5 (2000): 334-346.

21. Jaspreet Jain., et al. "In Vivo Evaluation of Withania somnifera Based Indian Traditional Formulation (Amukkara Choornam), Against Chikungunya Virus-Induced Morbidity and Arthralgia". Journal of Evidence Based Integrative Medicine 23 (2018): 1-7.

22. Vareed, SK., et al. "Blood-brain barrier permeability of bioactive with an amides present in Withania somnifera fruit extract". Phytotheraphy Research 28 (2014): 1260-1264.

23. Pitchiah Kumar M., et al. "Coronavirus Spike (S) Glycoprotein (2019-Ncov) Targeted Siddha Medicines Kabasura Kudineer and Thonthasura Kudineer -In silico Evidence for Corona Viral Drug". Asian Journal of Pharmaceutical Research and Health Care 1.2 (2019): 1-9.

24. Anti-Inflammatory, Antipyretic And Antibacterial Study Of Kabasura Kudineer Choornam (2017).

25. Gangarapu Kiran L., et al. "In Silico computational screening of Kabasura Kudineer- Official Siddha Formulation and JACOM 
against SARS-CoV-2 spike protein". Journal of Ayurveda and In-

tegrative Medicine 11 (2020): 1-2.

26. Murugesan Mudaliar and KS Gunapadam "Porut panbu NoolPart - 1, Moligai Vagupu", 7th ed, Department of Indian Medicine and Homeopathy. Government of Tamil Nadu, Chennai (2003).

27. Alexandra C Walls., et al. "Structure, Function and Antigenicity of the SARS-CoV-2 Spike Glycoprotein". Cell 2 (2020): 281-296.

28. Kalai arasi R., et al. "Combination Of Nilavembu Kudineer And Adathodai Manapagu In The Management Of Dengue Fever". International Journal of Current Research 5.4 (2013): 978-981.

29. Karthikeyen Lakshmanan., et al. "Screening of Kabasura Kudineer Chooranam against COVID-19 through targeting of main protease and RNA-dependent RNA polymerase of SARSCov-2 by molecular docking studies". (2020).

\section{Assets from publication with us}

- Prompt Acknowledgement after receiving the article

- Thorough Double blinded peer review

- Rapid Publication

- Issue of Publication Certificate

- High visibility of your Published work

Website: www.actascientific.com/

Submit Article: www.actascientific.com/submission.php

Email us: editor@actascientific.com

Contact us: +919182824667 